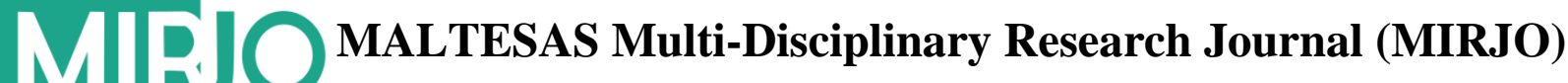

www.mirjo.maltesas.my

\section{Pengaplikasian Kerangka Semantik Inkuisitif Melalui Slanga}

\author{
(The Application of Inquisitive Semantic Approach Through Slang)
}

\author{
Muhammad Zaid Daud \\ Fakulti Bahasa dan Komunikasi, Universiti Malaysia Sarawak (UNIMAS), Jalan Datuk Mohammad Musa, \\ 94300 Kota Samarahan, Sarawak, Malaysia
}

Corresponding author: zaid_daud93@yahoo.com

\begin{abstract}
Abstrak. Slanga merupakan bahasa tidak formal yang telah digunakan dalam sesuatu kelompok komunitinya tersendiri malahan dapat menonjolkan identiti sesuatu kelompok masyarakat yang membawanya sebagai contohnya dalam kalangan remaja. Melalui ujaran slanga ini terdapatnya keimplisitan ujaran yang telah dikesan oleh pengkaji yang mampu dianalisis menggunakan pendekatan Semantik Inkuisitif (SI) oleh Nor Hashimah Jalaluddin (2014). Hal ini demikian kerana penganalisisan semantik inkuisitif sebelum ini hanyalah melibatkan data-data peribahasa - lihat kajian [6-9], [1820], [23-24], [26] dan [30]. Oleh itu, kajian ini cuba membuktikan bahawa dengan menggunakan slanga juga mampu dicungkil maknanya dengan menggabungkan data, teori, kognitif dan akal budi atau intelektual Melayu seperti mana kajian-kajian SI telah dijalankan sebelum ini. Sejumlah tiga data telah diperoleh daripada perbualan tidak formal masyarakat Melayu di sekitar Kuala Lumpur, Malaysia dan Kota Samarahan, Sarawak, Malaysia yang mengandungi slanga berimplisit yang akan dianalisis oleh pengkaji melalui pendekatan SI. Seterusnya, Rangka Rujuk Silang (RRS) juga diaplikasikan bagi membantu pengkaji mendapatkan anteseden tambahan kepada pengkaji dalam memahami konteks sebenar ujaran tersebut sehingga ke akal budi penuturnya.
\end{abstract}

Kata kunci- slanga; ujaran tidak formal; masyarakat Melayu; semantik inkuisitif(SI); rangka rujuk silang (RRS); akal budi Melayu

\begin{abstract}
Slang is an informal language that has been used in a distinctive community of groups, but can also identify the identity of a group of people who carry it as an example among adolescents. Through this slang there is an implicit utterance has been detected by researchers who can be analyzed using Inquisitive Semantic (IS) approach by Nor Hashimah Jalaluddin (2014). This is because the previous inquisitive semantic analysis only involves data of proverbs see [6-9], [18-20], [23-24], [26] and [30]. Therefore, this study attempts to prove that using the slang can also be interpreted in its meaning by combining data, theory, cognitive and intellectual or Malay intellectuals as IS studies have been conducted before. A total of three data was obtained from the informal conversations of the Malay community around Kuala Lumpur, Malaysia and Kota Samarahan, Sarawak, Malaysia which contained the immature slang that would be analyzed by researchers through the IS approach. Furthermore, the Cross-Reference Framework $(C R F)$ is also applied to help researchers gain additional antecedents to researchers in understanding the true context of the utterance to the mind of the speaker.
\end{abstract}

Keywords - slang; the informal utterance; Malay community; inquisitive semantic (IS); Cross Reference Framework (CRF); Malay mind 